\title{
Port Kateter Uygulamaları: Kanserli Hastaların Deneyimlerine İlişkin Niteliksel Bir Çalışma
}

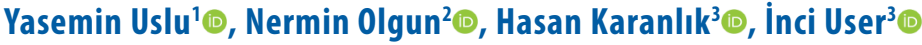

${ }^{1}$ Acıbadem Mehmet Ali Aydınlar Üniversitesi, Sağlık Bilimleri Fakültesi, Hemşirelik Bölümü, İstanbul, Türkiye ${ }^{2}$ Hasan Kalyoncu Üniversitesi, Sağlık Bilimleri Fakültesi, Hemşirelik Bölümü, Gaziantep, Türkiye ${ }^{3}$ Istanbul Üniversitesi Onkoloji Enstitüsü, Cerrahi Anabilim Dalı, İstanbul, Türkiye

${ }^{4}$ Acıbadem Mehmet Ali Aydınlar Üniversitesi, Fen-Edebiyat Fakültesi, Sosyoloji Bölümü, İstanbul, Türkiye

Yasemin Uslu, Öğr. Gör. Dr. Nermin Olgun, Prof. Dr. Hasan Karanlık, Prof. Dr. Inci Use, Prof. Dr.

İletişim:

Öğr. Gör. Dr. Yasemin Uslu

Acıbadem Mehmet Ali Aydınlar Üniversitesi,

Sağık Bilimleri Fakültesi, Hemşirelik Bölümü, İstanbul, Türkiye

Tel: +902165004167

E-Posta:yaseminuslu86@gmail.com
ÖZET

Amaç: Bu çalışmanın amacı kanserli hastaların taşıdıkları port kateterlere ilişkin algı ve deneyimlerini ortaya çıkarmaktır.

Gereç-yöntem: Çalışma, İstanbul'da bir onkoloji kliniğine tedavi için başvuran, 16 kanser hastasıyla derinlemesine görüş̧meler yoluyla yapılmıştır. Çalışma grubuna en az 6 aydır port kateteri olan meme ve kolon kanserli hastalar alınmıştır. Çalışma temaları hastaların port deneyimlerini çok boyutlu olarak kavramayı hedefleyen: (1) Portun Öyküsü, (2) Sosyal Yaşam ve Fiziksel Uyum (3) Beden İmajı ve Cinsel Yaşam (4) Tedavi Süreci ve Öneriler dinamiklerini içeren yarı yapılandırılmış açık uçlu sorulardan oluşturulmuştur. Görüşmeler ses kayıt cihazıyla kayıt altına alınarak çözümlemesinde içerik analizi kullanıımıştır.

Bulgular: Çalışmada elde edilen önemli bulgular, port kateterin hastaların cinsel yaşamı ve beden imajını etkileyebileceği, tedirginlik ve korku nedeniyle sosyal izolasyon yaşayabilecekleri gibi dezavantajları bulunurken, tedavide kolaylık ve hastayı tedavi sürecinde özgürleştirerek rahatık sağladığı için avantajlı olduğu belirlenmiştir.

Sonuç: Port kateteri olan kanserli hastaların gereksinim duyduğu bakımın sürdürülmesinde var olan temel ilkelerin yanı sıra hasta deneyimlerinin ve port kateterin psikososyal boyutunun da bilinmesi, bakım kalitesinin arttırılması açısından önemlidir.

Anahtar sözcükler: port kateter, vasküler erişim, beden imajı, kanser, niteliksel çalışma

\section{PORT CATHETER APPLICATIONS: A QUALITATIVE STUDY ON EXPERIENCES OF PATIENTS WITH CANCER.}

\section{ABSTRACT}

Objective: The aim of this study is to identify cancer patients' experiences related to port catheters.

Methods: This study was done with 16 patients, who applied to the oncology clinic for treatment, by using in-depth interview technique. The study group consists of colon cancer and breast cancer patients having port catheters for at least six months. The themes of the study are comprised of four open-ended questions, which aimed to comprehend the patients' port experiences in a multidimensional way. These questions are based on (1) story of the port, (2) social life and physical adaptation, (3) sexual life and body image, and (4) treatment process and dynamic recommendations related to living with the port.

Results: The important findings obtained from the study are twofold. First, the port catheter has disadvantages, such as influencing patients' sexual lives and body images, and leading to social isolation through(by) creating anxiety and fear. Second, the port catheter has also advantages, such as providing convenience to patients during the treatment, and giving comfort to them during the treatment by making them free.

Conclusions: One of the important principles related to port catheter that it provides a reliable care to the patients. In this direction, in addition to the fundamental principles related to the maintenance of the care needed by the cancer patients with port, knowing the psychosocial aspect of the port and patient experiences is very important to increase the quality of the care given.

Keywords: port catheter, vascular access, body image, cancer, qualitative study. 
O nkoloji hastalarına kemoterapi, kan transfüzyonu ve tedavi amacıyla tekrarlayıcı damar yolu girişimleri sıkça uygulanmaktadır. Her işlem için yen bir damar yolu açmak yerine santral venöz kateterler ve implante edilen port sistemlerinin kullanımı vasküler erişimde büyük kolaylık sağlaması sebebiyle onkoloji kliniklerinde sık tercih edilmektedir $(1,2)$.

Vasküler portlar, ilk kez Niederhuber ve arkadaşları tarafından 1982 yılında tanımlanmıştır. Bunlar tekrarlanan ilaç uygulamaları için güvenli ve kolay damar girişi sağlayan, cilt altına yerleștirilen kateterlerdir (2). Doğru cerrahi teknikle yerleştirilen port kateterler, bakım ve uygulamaların kurallara uygun yapılması durumunda diğer santral venöz kateterlere göre daha kullanışlıdır $(3,4)$. Bunun nedenleri port kateterin onkoloji hastalarında uzun süreli ve aralıklı kemoterapiler için en uygun araç olması, hastanın kişisel ve özel hayatındaki faaliyetlerini kesintiye uğratmaması, deri altına yerleştirildiğinden psikolojik sorun yaratmadığının düşünülmesi, tromboz ve enfeksiyon oranının daha düşük olması, dışarıdan bir pansuman ya da müdahale gerektirmemesidir. Uygulanan tedavi sırasında daha az sayıda iğne girişimi yapılacağı için hastaların daha az anksiyete yaşamaları da port kateterlerin önemli bir avantajı olarak görülmektedir $(5,6)$. Port kateterler damar erişiminde kaygı, ağrı ve rahatsızlığı azaltan etkin ve etkili bir yöntem olduğu belirtilmesine rağmen yaşam kalitesini artırdığına yönelik göze çarpan etkisi bulunmadığı belirtilmektedir (7). Literatürde port kateterlerin yaşam biçiminde kolaylık sağladığı, vücut imajını bozmadığı, günlük aktivitelerde kısıtlama yaratmadığı ve estetik görünüş açısından hastaların bu kateterlere kolay uyum sağladığı belirtilmesine rağmen, hastaların bu konudaki deneyimlerine ve öznel değerlendirmelerine ilişkin herhangi bir çalışmaya rastlanmamıştır. Çalışmanın temel amacı, kanserli hastaların taşıdıkları port kateterlere ilişkin algı ve deneyimleri ortaya çıkarmaktır.

\section{Yöntem}

İnsanların olaylar karşısındaki davranışlarının araştırılması esnek ve bütüncül bir yaklaşımla mümkündür. Bu nedenle niteliksel yaklaşımlarda bireylerin görüş ve deneyimleri büyük önem taşımaktadır (8). Çalışma, hastaların öznel algı ve deneyimlerinin anlaşılmasını hedeflediği için, niteliksel yöntemin kullanılması planlandı ve veri oluşturma tekniği olarak derinlemesine görüşmelerden yararlanıldı.

Port kateter takılması birçok farklı kanser türünde uygulanmasına rağmen en sık meme ve kolon kanserli hastalarda uygulanması nedeniyle kolon ve meme kanserli hastalar örneklem grubuna seçildi. En az altı aydır port kateteri olan meme ve kolon kanserli bireyler örneklem grubuna alındı. Mastektomi ameliyatı ve stoması olan hastalar, beden imajı ile ilgili yaşadıkları sorunun port kateteri varlığını gölgeleyebileceğinden dolayı örneklem dışı bırakıldı. Bu nedenle örneklem grubuna alınan hastalarda beden bütünlüğünün korunuyor olması tercih edildi. Beyin metastazı ve nörolojik bir sorunu olan, herhangi bir psikolojik hastalığı olan, konuşma engeli olan bireyler çalışmaya dâhil edilmedi.

\section{Verilerin toplanması ve analizi}

Araştırmanın örneklem seçiminde amaçlı örnekleme tekniğine başvuruldu $(9,10)$. Yönerge, kanser tanısı konulduktan görüşmenin yapıldığı süreye uzanan zaman diliminde hastaların: (1) Portun Öyküsü, (2) Sosyal Yaşam ve Fiziksel Uyum (3) Beden İmajı ve Cinsel Yaşam (4) Tedavi Süreci ve Öneriler dinamiklerini içeren port deneyimlerini çok boyutlu olarak kavramayı hedefleyen açık uçlu sorulardan oluşturuldu (Şekil 1).

\section{Derinlemesine görüşmeler}

Çalışmanın uygulama aşamasında, İstanbul'da bulunan bir onkoloji kliniğine Mayıs-Haziran 2012 tarihlerinde tedavi için başvuran, 16 kanser hastasıyla derinlemesine görüşmeler yapılarak veri toplandı. Görüşmeler katılımcıların doğal ortamları olan kendi evlerinde ya da hastanelerdeki görüşme odalarında gerçekleştirildi. Görüşmeler asgari 40 ila azami 160 dakika arasında (ortalama 55 dakika) sürdürüldü. Derinlemesine görüşmeler veri doyumunun sağlandığı yeni ve farklı bilgilerin gelmez olduğu noktada (16 hasta) veri toplanması sonlandırıldı. Görüşmelerde, katılımcıların izni alınarak ses kayıt cihazı kullanıldı ve her görüşmenin yazılı dökümü en fazla 24 saat içinde çıkartıldı. Veriler yazılı hale getirilirken üzerinde hiçbir değişiklik yapılmayıp hastaların ifade ettiği şekilde yazıya geçirildi.

\section{Derinlemesine görüşmelerin analizi}

Niteliksel yaklaşıma dayalı bu çalışmanın 16 derinlemesine görüşmeden elde edilen verileri, yazılı çözümü yapılmış görüşme çıktıları üzerinden içerik analizi yapıldı. Okuma, gruplandırma, temalaştırma aşamalarında Microsoft Word 2007 kelime işlemci yazılımından da yararlanıldı. Analiz sürecinde tüme varımcı bir anlayış izlenerek, üzerinde durulan konuyla ilgili ifade edilen kavramların ve düşüncelerin temalaştırılması, görüşmenin çözümlendiği metnin tekrar tekrar okunması ile sağlandı; bu temalar çalışmanın alt amaçlarına göre kodlanıp gruplandırıldı (11).

\section{Etik hassasiyetler}

Çalışmanın yapılması için, Acıbadem Üniversitesi Etik Kurulu'ndan uygulama izni alındı. Çalışmaya katılmaya 
gönüllü olan katılımcılardan ses kayıt cihazı ile seslerinin kaydedilmesi konusunda onamları alındı. Çalışmada görüşleri aktarılan kanser hastalarının gerçek isimleri ve kendilerini tanıtabilecek ilave bilgiler, mahremiyetlerinin korunması etik ilkesi çerçevesinde gizli tutuldu. Her bireye kendilerinin seçmiş olduğu bir rumuz verildi. Hasta tanıtıcı bilgileri tablo 1'de belirtilmiştir.

\section{Bulgular}

Çalışma kapsamında görüşme yapılan hastaların \%68,7'i $(n=11)$ kadın, \%31,2'i $(n=5)$ erkek olup \%56,2 ( $n=9)$ kolon kanseri ve \%43,7'si $(n=7)$ meme kanseridir. Yapılan derinlemesine görüşmeler kapsamında; portun öyküsü (1), sosyal yaşam ve fiziksel uyum (2), beden imajı ve cinsel yaşam (3), tedavi süreci ve öneriler (4) olmak üzere dört tema ve 11 alt tema oluşturuldu (Şekil 1).

\section{Tema: Portun öyküsü}

Port takılma sürecinin hastada yarattığı etkileri bilmek bakım sürecinin yönetiminde önemlidir. Bu temada port takılma zamanı ve yeri, hangi bölgeye takıldığı, port takılma kararını kimin verdiği, karara verilen tepki, porta uyumun nasıl olduğu, takılma sonrasında uyumsuzluk yaşanıp yaşanmadığı yönündeki algılamalar değerlendirildi.

\section{Port kateter takalım mı?}

Katılımcıların çoğunluğu (12 kişi) port kateter takılma kararını hekimin verdiğini ifade etmişlerdir.

...ben doktorla konuşmadan önce beni çağırdı her şeyimi hazırlamışlar bana bunu yap dediler ben de yaptım... ne olduğunu bilmiyorum derinin altına bir şey takılacak dediler bana. Hiç bilmiyordum hiç duymamıştım da ilk defa o zaman duydum...(Narin)

Katılımcılar (13 kişi) port kateter takılma sürecine ilişkin bilgileri olmadığı ve sürecin stresli olduğunu aşağıdaki şekilde belirtmişlerdir.

...doktor öncesinde söyledi bayıltmıyorlar dediler orda tedirgin oldum korktum. Uyumak istedim bayıltsınlar beni görmiyim duymiyim dedim. Portu hiç görmemiştim başkasında da görmemiştim. Gülle gibi bir şey cildin altına takılacak dedi doktor sesimi çıkaramadım bende sustum... (Zeynep)

\section{Tablo 1. Hasta tanitıcı bilgileri}

1. Cem: 56 yaşında, erkek. Üniversite mezunu. Kolon CA. Hastalığının tanısı yaklaşık beş yıl önce konulmuş. 5 yıldır port kateteri mevcut. Gördüğü tedaviler; cerrahi, kemoterapi.

2. Ece: 62 yaşında, kadın. İlkokul mezunu. Meme CA. Hastalığının tanısı yaklaşık bir yıl önce konulmuş. Dokuz aydır port kateteri mevcut. Gördüğü tedaviler; cerrahi, kemoterapi.

3. Ersin: 59 yaşında, erkek. İlkokul mezunu. Kolon CA. Hastalığının tanısı yaklaşık iki yıl önce konulmuş. İki yıldır port kateteri mevcut. Gördüğü tedaviler; cerrahi, kemoterapi.

4. Fatma: 60 yaşında, kadın. İlkokul mezunu. Meme CA. Hastalığının tanısı yaklaşık 11 yı önce konulmuş. 2 yıldır port kateteri mevcut. Gördüğü tedaviler; cerrahi, kemoterapi, radyoterapi

5. Kamer: 50 yasında, kadın. Illkokul mezunu. Kolon CA. Hastalığının tanısı yaklaşık bir yı önce konulmuş. Bir yıldır port kateteri mevcut. Gördüğü tedaviler; cerrahi, kemoterapi.

6. Salim: 67 yaşında, erkek. Üniversite mezunu. Kolon CA. Hastalığının tanısı yaklaşık bir yıl önce konulmuş. Bir yıldır port kateteri mevcut. Gördüğü tedaviler; kemoterapi.

7. Zeynep: 61 yaşında, kadın. Illkokul mezunu. Kolon CA. Hastalı̆ın tanısı yaklaşık iki buçuk yıl önce konulmuş. İki buçuk yıldır port kateteri mevcut. Gördüğ̈̈ tedaviler; cerrahi, kemoterapi

8. Nigar: 52 yaşında, kadın. İlkkokul mezunu. Kolon CA. Hastalığın tanısı yaklaşık alıı ay önce konulmuş. Altı aydır port kateteri mevcut. Gördüğü tedaviler; kemoterapi

9. Merve: 42 yaşında, kadın. Üniversite mezunu. Meme CA. Hastalığın tanısı yaklaşık dört yı önce konulmuş. iki yıldır port kateteri mevcut. Gördüğü tedaviler; cerrahi, kemoterapi, radyoterapi

10. Gizem: 32 yaşında, kadın. İlkokul mezunu. Meme CA. Hastalığın tanısı yaklaşık alıı yıl önce konulmuş. Bir buçuk yıldır port kateteri mevcut. Gördüğü tedaviler; cerrahi, kemoterapi, radyoterapi

11. Narin: 37 yaşında, kadın. Illkokul mezunu. Meme CA. Hastalığın tanısı yaklaşık iki yıl önce konulmuş. Bir yııdır port kateteri mevcut. Gördüğü tedaviler; cerrahi, kemoterapi, radyoterapi

12. Kıymet: 50 yaşında, kadın. Illkokul mezunu. Kolon CA. Hastalığın tanısı yaklaşık üç yıl önce konulmuş. Üç yııdır port kateteri mevcut. Gördüğü tedaviler; cerrahi, kemoterapi, radyoterapi

13. Sıdıka: 47 yaşında, kadın. Üniversite mezunu. Meme CA. Hastalığın tanısı yaklaşık on yıl önce konulmuş. Altı yıldır port kateteri mevcut. Gördüğü tedaviler; cerrahi, kemoterapi, radyoterapi

14. Selahattin: 62 yaşında, erkek. Illkokul mezunu. Kolon CA. Hastalığın tanısı yaklaşık iki yı önce konulmuş. İki yıldır port kateteri mevcut. Gördüğü tedaviler; cerrahi, kemoterapi

15. Salih: 65 yaşında, erkek. Ortaokul mezunu. Kolon CA. Hastalığın tanısı yaklaşık üç yıl önce konulmuş. Üç yıldır port kateteri mevcut. Gördüğü tedaviler; cerrahi, kemoterapi

16. Gönül: 59 yaşında, kadın. İlkokul mezunu. Meme CA. Hastalı̆ın tanısı yaklaşık on yıl önce konmuş. Dört yıldır port kateteri mevcut. Gördüğü tedaviler; cerrahi, kemoterapi, radyoterapi 


\section{Yarı Yapılandırılmış Görüşme Soruları}

Port kateter takılma sürecine kim nasıl karar verdi? Açıklayınız. Port kateter günlük fiziksel aktivitelerinizi nasıl etkiledi? Açıklayınız. Port kateter eşinizle olan cinsel yaşamınızı nasıl etkiledi? Açıklayınız. Port kateterin varlığı kıyafet seçiminizi nasıl etkiledi? Açıklayınız. Port katetere sosyal çevreniz nasıl tepki verdi? Açıklayınız. Port kateter tedavi sürecinizi nasıl etkiledi? Açıklayınız.

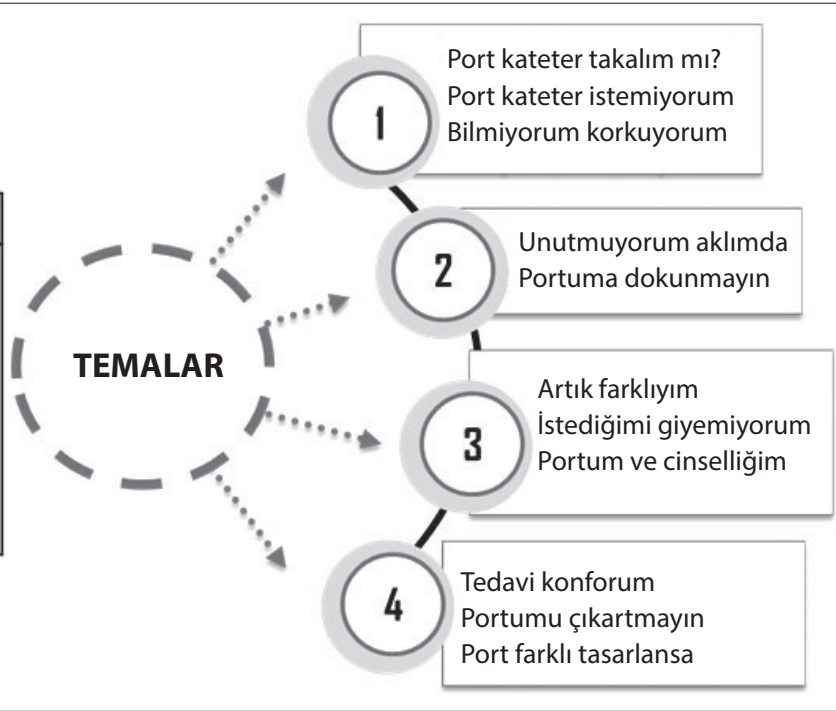

Şekil 1. Çalışma temaları

\section{Port kateter istemiyorum!}

Katılımcıların bazıları (8 kişi) port kateter takıldıktan sonra uyum sorunu yaşadıklarını ifade etmişlerdir.

...çok zor geçiyordu ilk takıldığında kemoterapi alacaksın dediler ama pompa takılacağını söylememişlerdi. Pompayı doldurdular getirdiler bunu üzerinde taşıcaksın... Allahım ben bunu nasıl taşıcam üzerimde iğne, elimde kocaman pompa nasıl yapıcam ben bu pompayla gezemem dedim istemiyorum almak istemiyorum tedavi dedim ağladım bıraktık, eve geldim... (Kamer)

\section{Bilmiyorum korkuyorum}

Port katerer konusunda bilgi almayan katılımcılar (8 kişi) yaşadıklarını şöyle ifade etmiştir;

...hemşireler hiç bir şey olmaz korkma deselerdi, rahat olur böyle deselerdi. Insanı bilinçlendirselerdi daha iyi olurdu... (Kıymet)

...ödem olduğunda bunun geçici bir şey olduğunu, geçince rahatlayacaksın denilebilir. Illk başlardaki o acının zaman içerisinde azalacağı söylenebilir. Çok korkuyor insan...(Merve)

\section{Tema: Sosyal yaşam ve fiziksel uyum}

Bu tema altında hastanın sosyal çevresinin düşünceleri, uyum güçlüğü, günlük yaşam aktivitelerindeki değişimler sorgulandı.

\section{Unutmuyorum aklımda}

Kadın katılımcılardan bazıları (6 kişi) port kateterin günlük yaşam aktivitelerini etkilediğini aşağıdaki şekilde ifade etmişlerdir. ...portu sıkıştıracak tarzda yatamıyorum. Port sayesinde sırt üstü yatmayı öğrendim yan yatıyorum ama porta doğru değil, unutmasa da vücut zamanla alışıyor, kendini ayarlıyor (Sıdıka)

...mesela iş yaparken falan farkındayım, portum hep aklımda. Yemek yaparken pek etkilemiyor ama iş yaparken ağrı veriyor. Yerleri falan silerken ağrı veriyor ama örgü yaparken hiç ağrım olmuyor...(Gönül)

\section{Portuma dokunmayın}

Katılımcılardan bazıları (5 kişi) port katetere zarar gelme korkusu nedeniyle izolasyon yaşadıklarını aşağıdaki şekilde ifade etmişlerdir:

...çocukları yanaştırmıyorum vururlar diye çocuğu bu tarafıma (portun olduğu taraf) alamıyorum. Kalabalığa binsem birisi vurur diye portumu koruyorum, emniyete alıyorum. Çocuk sevsem, torunlarımı diğer tarafıma oturtuyorum kafasını vurur diye korkuyorum. Tedirginliğim yok ama yine de koruyorum biryere vurmamak için... (Kıymet)

\section{Tema: Beden imajı ve cinsel yaşam}

Bu tema altında port kateteri olan hastanın eşi ile ilişkisi, cinsel yaşamda değişiklikleri, eşinin porta dokunması, güzellik ve çekiciliğini yitirme kaygısı, port kateterin belli olması, dışardan hissedilmesi, takıldığı bölgenin cinselliğe etkisi, kıyafet değişikliği, port kateteri belli eden kıyafet seçimi sorgulandı.

\section{Artık farklıyım}

Katılımcıların bazıları (5 kişi) port kateterin kendilerine farklılık kattığını ve rahatsızlık hissetmediğini aşağıdaki şekilde ifade etmişlerdir: 
...iki sene oldu iki sefer tatile gittim denizime girdim hiçbir sorun olmadı. Gözükmesi de hiç umurumda değil, soranda olmadı sorarlarsa da ilaç alıyorum rahatsızım derdim. Eşim dokunuyor, bazen başını koyuyor dikkat et patlar diyorum şaka yapıyorum (Ersin)

...farklı olmayı seviyorum... Elim gitmiyor oraya, unutuyorum bazen, kapalı bir şey giydiğimde hiç farkında değilim. Beni imaj olarak hiç etkilemedi. Zararlı olmasa üzerine dövme yaptırırım, gül figürü mesela güzel olurdu ama zararından korktuğum için yaptırmadım... (Fatma)

\section{İstediğimi giyemiyorum}

Katılımcılardan kadın olanların çoğunlukla (8 kişi) kıyafet seçimleri ve tercihlerinin değiştiğini ifade etmişlerdir.

...hastaneye gelirken boğazlı kıyafet giyemiyorsun genelde yakası açık giyiyorsun. Çünkü porttan ilaç verilecek boğazlıdan nasıl açıpta takılacak... Yakası açık giymek zorundasın. Kıyafet değişti mecburen. Hastaneye gelirken kısa şeyler giyiyorsun... (Gizem)

...açık giyinemiyorum bütün kıyafetlerin hepsi duruyor, kaldırdım kıyafetleri. Giymiyorum giyemiyorum, görünecek diye giyemiyorsun, görünmesini istemiyorsun...(Kamer)

\section{Portum ve cinselliğim}

Katılımcılardan kadın olanların çoğunlukla (6 kişi) cinsel yaşamlarında değişim olduğunu ifade ederken erkek hastaların (4 kişi) cinsel yaşamlarında değişiklik olmadığı aşağıdaki şekilde ifade edilmiştir.

...hastalığımla ilgilenmedi ki portu sorsun (eşinden bahsediyor). İsterdim onun sıcaklığını, merak etsin ilgilensin, kim istemez ki. Ben sürekli tedirginim yatınca eli muhakkak oraya dokunur bişi olursa kayarsa acırsa diye korkardım, rahatsız olurdum... (Kamer)

...benim eşlerim açısından sorun olmadı, soruyorlar, merak ediyorlar. Cinsel aktivite sırasında oraya temas edince sert bir şey geldiğinde vurduğunda acıyor orası, o zaman portu hissediyorum... Denizde yüzerken pil diyorum ama beraber olduğun insana anlatmak zorunda kalıyorsun... (Cem)

\section{Tema: Tedavi süreci ve öneriler}

Bu tema altında hastanın tedavi sürecinde port katetere ilişkin deneyimleri, port kateter kullanımını tavsiye etme/ etmeme, port kateterin daha etkin kullanımı için önerileri, port kateterin çıkarılma zamanı sorgulandı.

\section{Tedavi konforum}

Port kateterin kemoterapi tedavisi sırasında damar yolu erişimi olarak konforlu olduğunu düşünen katılımcılara (7 kişi) bakıldığında;

...Bunda bir seferde bulmaları, canın çok acımaması bana çok büyük rahatlık veriyor, ilaç giderken hiç hissetmiyorum, koldan ilaç giderken ağrı oluyor ama portta sanki hiç ilaç almıyor gibiyim, hissetmiyorum... Damarı bulamayınca tekrar tekrar kaç kere deliniyor sıkıntı oluyor, port şuanda çok büyük rahatlık ve lüks geliyor...(Merve)

Port kateteri kendinde üstünlük olarak gören ve kendini ayrıcalıklı hisseden Cem duygularını şöyle ifade etmiştir;

...Diğerlerine iğne takılıyor çıkarılıyor bulunmuyor, herkeste yok çünkü (portu kastediyor)... Kendimi üstün görüyorum, diğerleri normal vatandaş gibi geliyor bana. Onlar 15 dk. uğraşıyorlar, benimki bir dakikada takılıyor, yıkaması da kolay... (Cem)

Tedavi alma sürecinde ellerini kullanabilmenin özgürlük olduğunu düşünen Gönül şöyle ifade etmiştir;

...elimdeki örgü olmadan bir yere adım atmıyorum illa ya lif örücem ya da örgü örücem. Bunları öremediğim zaman bulmaca çözemediğim zaman rahatsız oluyordum. O kadar sevindim ki şimdi tedavi alırken iki kolum da özgür... (Gönül)

Port iğnesi nedeniyle korku ve tedirginlik yaşayan Kamer şöyle ifade etmiştir;

...lğne takılacak diye dünden psikolojim çöktü, çok strese girdim. Sabah otobüste gelirken düşünüyorum vücudum yorgun bitkin kendi kendime sordum daha dur ilacı almadın dedim, ilacı almadan daha iğne korkusu başıyor. (Kamer)

Damar erişim problemi yaşanmayan hastalarda port kateter uygulamasını önermeyen Sıdıka şöyle ifade etmiştir;

...Damar bulmada problemi yoksa bence takılmasın. Ben taktırdım çünkü damarlarım yandı, büzüldü, gerildi, kolumu açamıyordum hala o sertlikler duruyo hissediyorum. Damar problemim olduğu için şuan memnunum ama damar problemi yoksa takılmasın bence. (Sıdıka)

\section{Portumu çıkartmayın}

Katılımcıların çoğu (10 kişi) port kateterinden memnun olduğunu ve çıkartmak istemediğini ifade etmişlerdir. 
...hiç çıkarmıcam, tedavi bitsede kalsın. Ne zaman ne olacağı belli olmuyo. ikinciyi aldım(kemoterapi) belki de üçüncüyü almam gerekecek. Komplikasyon yaratmadığı müddetçe kalsın...(Cem)

Vücudunda yabancı bir cismin varlığından rahatsızlık duyan Kamer duygularını şöyle ifade etmiştir;

...istemiyorum orda durmasını beni rahatsız ediyo, tedavi biter bitmez randevuyu verseler de ertesi gün çıkartsalar. Vücudumda bişi kalmasın artık diyorum çünkü çok şey yaşandı çok yoruldum, uğraştım... (Kamer)

\section{Port farklı tasarlansa}

Katıımcılardan bazıları (4 kişi) port kateterin yerleşim yerinden memnuniyetini aşağıdaki şekilde ifade etmiştir.

...burası (göğüs) daha emniyetli, elini koyuyorsun koruryosun. Burası daha uygun elini kapatırsın kimse değmesin diye, koruyabiliyorum burada olunca... (Kıymet)

Port kateterin şeklinden rahatsızlık duyan kadın hastalardan bazıları (5 kişi) şöyle ifade etmiştir;

...Aynada orda bir çıkıntı olması hoşuma gitmiyor keşke daha küçük olsaydı görünmeseydi diyorum. Acaba farklı bir boyutta var mı diye düşündüm... (Merve).

...mesela daha görünmez bir yere, onu gizleyebileceği bir yere takılabilirdi birinde görmüştüm kasığında vardı. Göğüste çok gözüküyor, kasıkta olsa daha mantıklı. Daha kolay kapatılabilir (Kamer).

\section{Tartışma}

Kanser hastalarında port kateterlerin kullanılmaya başlanması bu alandaki en önemli gelişmelerdendir. Bu bölümde port kateterlere ilişkin hastaların algı ve deneyimlerine ilişsin bulgular tartışılmıştır.

Çalışmada, port takılacak olan hastaların işlem öncesinde böyle bir kateterin varlığından haberdar olmadıkları ifade edildi. Kolon kanseri olan hastalar tedavileri gereği port takılmasına doktor tarafından karar verildiğini, meme kanseri olan hastalar ise port kararına diğer hastaların önerileri doğrultusunda ya da hekim, hemşire tarafından yönlendirildikleri belirtildi. Port takılma kararı verildiğinde hasta ile işbirliği yapılmadığı ve öncesinde hastaların bilgilendirilmedikleri belirlendi. Bilinmeyene karşı duyulan korku ve tedirginliğin cerrahi işlem öncesi çok fazla olduğu ifade edildi. Benzer şekilde yapılan çalışmalarda tanı ve tedavi amaçlı yapılan birçok işlemde uygulama öncesinde ve sonrasında hastaların korku ve anksiyete düzeylerinin yüksek olduğu belirtilmektedir $(12,13)$.

Literatürde port kateterin lokal anestezi altında yerleştirilmesinin, hastaya daha az rahatsızlık vermesi gibi üstünlükleri olduğu belirtilmesine rağmen $(14,15)$ bu çalışmada bazı hastalar lokal anesteziden rahatsızlık duyduklarını, işlem basitte olsa işlemin farkında olmaktan tedirgin oldukları ifade edildi. Bazı hastalar ise lokal anestezi ile yapılmasını avantaj olarak görüp bu süreç esnasında korku ve tedirginlik yaşamadıkları belirtildi. Port kateter sonrası erken dönemde port etrafındaki ağrı, ödem ve hematom nedeniyle bazı hastaların tedirgin oldukları, korktukları ve uyum güçlüğü yaşadıkları ifade edildi. Port kateter hakkında bilgilendirilen hastaların tedirginlik ve korkularının daha az olduğu, bilgilendirilmeyen hastaların ise erken dönemde yaşanan sorunlardan çok fazla etkilendikleri saptandı. Literatürde hasta eğitiminin, hastalarda anksiyeteyi azalttığı, stresle başa çıkmayı geliştirdiği ve hasta memnuniyetinde önemli rol oynadığı belirtilmektedir (16-18). Bu çalışmada, hastaların genellikle ilk birkaç ayda uyum sorunu yaşadıkları ancak sonraki süreçte uyum sağladıkları belirlendi. Konu ile ilgili hastaların çelişkili ifadelerinin olduğu belirlenmiş olup port kateter takılmadan önce sedasyon türüne ilişkin hasta tercihlerinin sorgulanmasının uygun olacağı düşünülmektedir. Benzer şekilde Usta Yeşilbalkan ve arkadaşlarının yaptığı çalışmada (2009) kanserli hastaların port kateter hakkındaki bilgilerinin yetersiz olduğu belirtilmektedir (19). Port konusunda yeterli bilgisi olmayan hasta yakınlarının da, hastanın porta olan uyumunu etkileyebileceği düşünülmektedir.

Çalışma kapsamında hastaların port katetere ilişkin bilgi yetersizliğinin porta fiziksel uyumda güçlüklere neden olduğu düşünülmektedir. Özellikle porta daha kolay uyum sağlayan ve imajını etkilemediğini düşünen erkek hastalarda fiziksel uyumun daha fazla olduğu düşünülmektedir. Beden imajını etkilediğini düşünen ve yeterli bilgisi olmayan kadın hastalarda fiziksel uyumun daha geç ve güç olduğu düşünülmektedir. Hastaların en çok port takılı olan tarafın üzerine yatmada, o taraftaki kolu aktif kullanmada, ağırlık kaldırmada ve ev işlerini yapmada güçlük yaşadıkları ifade edildi. Erkek hastaların ise fiziksel kısıtlılığı erken dönemde yaşadıkları ancak sonrasında yaşamadıkları ifade edildi. Port kateterin takıldığı erken dönemde porta bir şey olacak korkusu ile uyuma pozisyonunda ve kolun aktif kullanılmasında tedirginlik yaşandığı belirlendi. Günlük yaşam aktiviteleri sırasında port kateterin kendini hissettirdiği ifade edilmektedir. Nagel ve arkadaşlarının (2012) yaptığı çalışmada port kateterin hastalarda günlük yaşam 
aktivitelerini engellemediği ve boş zamanlarını etkin kullandıkları ifade edilmesine rağmen (20) bu çalışmada port kateteri koruma duygusuyla hastaların sosyal izolasyon yaşadığı düşünülmektedir.

Fiziksel görünümdeki değişiklik ya da fonksiyon kaybının önemi bireyin değişikliği nasıl algıladığına bağlıdır. Beden ya da beden parçasının önemi arttıkça, beden imajında hissedilen değişimde artmaktadır. Çeşitli nedenlerle vücudun her hangi bir bölümünün görünümü değiştiği zaman, beden imajı da değiş̧ebilmekte ve birey kendini tamamen farklı görebilmektedir (21). Stoması olan kadınların ameliyat sonrası beden imajı değerlendirildiğinde, kendilerini daha az çekici hissettikleri belirlenmiştir (22). Literatürde meme kanseri ile ilgili en fazla göze çarpan sorunlar arasında, kadınların vücutlarında meydana gelen değişiklikten rahatsızlık duymaları ifade edilmektedir (23). Bu çalışmada ise port kateterin, dışardan belli olmasının hastaları rahatsız ettiği, erkek hastaların beden görüntüsü hakkında rahatsızlıklarının kadınlardan daha az olduğu ve cinsiyetin beden imajı üzerinde etkili olduğu düşünülmektedir. Yapılan çalışmalarda da benzer şekilde hastaların port kateterin görüntüsüne ilişkin şikâyetlerinin olduğu ancak buna rağmen memnun oldukları belirtilmektedir $(20,24)$. Beden imajına yönelik sorunlar hastaların tedavi sürecinde uyumunu etkilediği gibi $(25,26)$ eşler arasındaki ilişkiyi de zedeleyebileceği belirtilmektedir (27).

Kanser olgusu, fiziksel bir hastalık olduğu gibi, psikolojik bileşkeleri de yoğun olan bir sorundur. Bu dönemde hastalara aileleri ve arkadaşları tarafından sağlanan sosyal desteğin kanser hastalarının genel iyilik halini etkileyerek hastalığın seyrinde olumlu sonuçlar meydana getirdiği bilinmektedir $(28,29)$. Kanser hastalarının sahip olduğu en önemli sosyal destek sistemi olan hasta yakınları incelendiğinde, hastaların sosyal desteği en çok eşlerinden aldıkları belirtilmektedir (5). Özellikle meme kanseri, genç yaştaki hastaların eşleri tarafından travmatik bir olay olarak algılanmakta, evlilik hayatı olumsuz olarak etkilemektedir (30). Çalışmalarda, kanserli kadınların eşlerinden duygusal destek bekledikleri ve gördükleri destekle hastalık sürecine daha kolay uyum sağlayabildikleri bildirilmektedir $(31,32)$. Kanser hastalarıyla yapılan bir çalışmada beden algısı daha yüksek olan bireylerin, eşleri ile daha uyumlu olduğu, beden algısı düşük olan hastaların cinsel olarak daha sık kaçınma ve dokunamama sorunu yaşadıkları ifade edilmektedir (33). Bu çalışmada erkek hastalar, port kateterin cinsel yaşamlarını etkilemediğini ifade ederken bazı kadın hastaların olumsuz etkilendikleri ve katetere zarar geleceği korkusu nedeniyle eşleriyle cinsel birliktelikten uzak durdukları saptandı. Kanser tedavi sürecinde eşler arasında sessiz tutumun sağlıklı uyumu zorlaştırdığı, eşlerin hastalıkla ilgili konuşmaktan kaçınmalarının birbirlerinden uzaklaşmalarına yol açarak evlilik ilişkisini olumsuz yönde etkilediği bilinmektedir $(34,35)$. Bu çalışmada da benzer şekilde kadın hastaların eşlerinden duygusal destek bekledikleri açıkça ifade edilmektedir.

Port kateterler, özellikle kanser hastalarında uzun dönemli kemoterapi uygulanacaksa periferik venöz yolun yaratacağı problemlerden kaçınmak için sıklıkla kullanılmaktadır (36). Çalışma kapsamında tekrar tedavi gereksinimi olabileceği kaygısı yaşayan ve uyum sağlayabilen hastalar portun kolaylık sağladığını belirterek çıkartılmasını istemezken, uyum sağlayamayan bazı hastaların tedavi biter bitmez çıkartmak istedikleri belirlendi. Uyumun sağlanmasında hasta eğitiminin çok önemli olduğu düşünülmektedir. Port kateter takılma süreci ve takibine ilişkin mutlaka hasta eğitiminin yapılması önerilmektedir. Etkin bir hasta eğitiminin, hastada port komplikasyonlarını azaltarak yaşam kalitesini arttıracağı belirtilmektedir (37). Port kateter bakımında hasta ile birlikte ailesinin de bakıma katılması ve port katetere ilişkin bilgilendirilmesi önerilmektedir (38,39).

Port kateter, santral venlerin dışında organ veya bölgesel arterlere de yerleştirilmektedir (40). Literatüre göre, port kateterler en sık göğüs ön duvarına yerleştirilmekle birlikte karın, kasık veya kol antekübital alana da takılabilmektedir $(41,42)$. Bu çalışmada port kateterin uygulama alanı olarak göğüs ön duvarında olmasının beden imajı açısından rahatsızlık verse de kullanımının daha kolay olduğu ve güvenilir alanda yerleşiminin onları rahatlattığı ifade edildi. Port kateterin boyutlarına ilişkin farklı boy ve ölçüde modellerin geliştirilmesi hastaların konforu açısından faydalı olabileceği düşünülmektedir. Port kateter, hastalar açısından birçok avantajı olmasıyla birlikte sağlık profesyonelleri açısından hemşirelik bakım kalitesini de artırmakta ve tedavilerin daha kolay ve sorunsuz sürdürülmesini sağlamaktadır $(43,44)$.

\section{Sonuç}

Venöz erişim yolu, tedavi süreci içinde hastaya kaliteli yaşam sağlayan bir köprü gibidir. Port kateterlerde venöz açıklığın devamının sağlanması, fonksiyonel yetersizliklerin azaltılması ve giderilmesi hemşirelik yaklaşımının temel basamaklarını oluşturur. Port kateteri olan hastaya bakım veren her hemşirenin, bütün hemşirelik uygulamalarında olduğu gibi, bu konu ile ilgili tüm işlem ve ilkelerin bilincinde olması, hastalara güvenli bakım verebilmesi 
için gereklidir. Hemşire, nitelikli bir hemşirelik bakımında, ani veya yavaş gelişen beden değişikliklerine uyum sürecinde; bireyin beden imajının nasıl etkilendiğini, değişen beden imajına uyumu, değişime karşı başkalarının tutum ve etkilerini, değişimle başa çıkmasında bireye nasıl yardım edebileceğini, girişimlerinin neler olabileceğini ve sonuçlarını belirlemesi gerekmektedir. Bu çalışmada elde edilen önemli bulgular, port kateterin hastaların cinsel

\section{Kaynaklar}

1. Rosenthal K. What you need to know about ports. Nursing 2006;36:20-1. [CrossRef]

2. Tuna Oran N. Port Kateter: Venöz Yolu Nasıl Sürdürebiliriz. Maltepe Üniversitesi Hemşirelik Bilim ve Sanatı Dergisi 2009;2:137-42. Erişim: $\quad$ https://www.researchgate.net/profile/Nazan_Oran/ publication/239281204_Port_Kateter_Venoz_Yolu_Nasil_ Surdurebiliriz/links/02e7e52d4e439455c7000000/Port-KateterVenoez-Yolu-Nasil-Suerduerebiliriz.pdf

3. Camp-Sorrell D. Accessing and deaccessing ports: where is the evidence? Clin J Oncol Nurs 2009;13:587-90. [CrossRef]

4. Fang S, Yang J, Song L, Jiang Y, Liu Y. Comparison of three types of central venous catheters in patients with malignant tumor receiving chemotherapy. Patient Preference and Adherence 2017;11:1197204. [CrossRef]

5. Özyurt BE. Kanser Hastalarının Algıladıkları Sosyal Destek Düzeyine İlişkin Betimsel Bir Çalışma. Kriz Derg 2007;15:1-15. Erişim: http:// dergiler.ankara.edu.tr/dergiler/21/957/11832.pdf

6. Usta Yeşilbakan Ö. Onkoloji hastalarında sık kullanılan venöz giriş aracı: İmplante port kateter. CÜ Hemşirelik Yüksek Okulu Dergisi 2005;9:49-54. Erişim: http://eskidergi.cumhuriyet.edu.tr/ makale/1153.pdf

7. Bow E, Kilpatrick $M$, Clinch J. Totally implantable venous access ports systems for patients receiving chemotherapy for solid tissue malignancies: a randomized controlled clinical trial examining the safety, efficacy, costs, and impact on quality of life. J Clin Oncol 1999;17:1267. [CrossRef]

8. Holloway I, Wheeler S. Qualitative Research for Nurses. Oxford: Blackwell Science Ltd.; 1996. pp.181-5.

9. Henwood K. Qualitative research. Encyclopedia of Critical Psychology 2014:1611-4.

10. Banister P, Dunn G, Burman E, Daniels J, Duckett P, Goodley D, et al. Qualitative methods in psychology: A research guide. UK: Open University Press: McGraw-Hill Education; 2011.

11. Erdoğan S. Nitel Araştırmalar. In: Erdoğan S, Nahcivan N, Esin MN, editörler. Hemşirelikte Araştırma Süreç, Uygulama ve Kritik. İstanbul: Nobel Tıp Kitabevi; 2014. pp.136-45.

12. Sidar A, Dedeli Ö, İşkesen A. Açık kalp cerrahisi öncesi ve sonrası hastaların kaygı ve ağrı distresi: Ağrı düzeyi ile ilişkisinin incelenmesi. Yoğun Bakım Derg 2013;4:1-8.

13. Karadeniz G, Tarhan S, Yanıkkerem E, Dedeli Ö, Kahraman E. Manyetik Rezonans ve Bilgisayarlı Tomografi öncesi hastalarda anksiyete ve depresyon. Klinik Psikiyatri 2008;11:77-83. Erişim: https://www. journalagent.com/kpd/pdfs/KPD_11_2_77_83.pdf

14. Bonczek R, Nurse B. Management of Port-A-Cath Devices in LongTerm Acute Care Hospitals. Rehabilitation Nursing 2012;37:307-11. [CrossRef] yaşamı ve beden imajını etkilediği, tedirginlik ve korku nedeniyle sosyal izolasyon yaşayabildikleri, tedavi sürecinde kolaylık sağlayarak bireyleri özgürleştirdiği şeklindedir. Bu doğrultuda, port kateteri olan hastaların gereksinim duyduğu bakımın sürdürülmesinde var olan temel ilkelerin yanı sıra hasta deneyimlerinin ve port kateterin psikososyal boyutunun da bilinmesi, bakım kalitesinin arttırılması açısından önemlidir.

15. Kaygın M, Dağ Ö, Güneş $M$, Şenocak M, Erkut B. Malign hastalarda intravenöz Port Kullanımı: 5 yıllık Klinik deneyim. Selçuk Tıp Derg 2012;28:17-21. Erişim: https://www.selcukmedj.org/uploads/ publications/SUTD-217.pdf

16. Sayin Y, Aksoy G. The effect of analgesic education on pain in patients undergoing breast surgery: within 24 hours after the operation. J Clin Nurs 2012;21:1244-53. [CrossRef]

17. Çetinkaya F, Karabulut N. Batın ameliyatı olacak yetişkin hastalara ameliyat öncesi verilen eğitimin kaygı ve ağrı düzeyine etkisi. Anadolu Hemşirelik ve Sağlık Bilimleri Derg2010;13:20-6.

18. Gürlek Ö, Yavuz M. Cerrahi kliniklerde çalışan hemşirelerin ameliyat öncesi hasta eğitimi uygulama durumları. Anadolu Hemşirelik ve Sağlık Bilimleri Derg 2013;16. Erişim: https://dergipark.org.tr/ download/article-file/29629

19. Usta Yeşilbalkan Ö, Kır S, Karadakovan A, Uslu R. Knowledge and attitudes of Turkish cancer patients regarding the implantable port catheter. Türk Onkoloji Derg 2009;24:108-14.

20. Nagel S, Teichgräber U, Kausche S, Lehmann A. Satisfaction and quality of life: a survey-based assessment in patients with a totally implantable venous port system. Eur J Cancer Care 2012;21:197204. [CrossRef]

21. Ayaz S. Stomalı Bireylerde Beden İmajı ve Benlik Saygısı. Turkiye Klinikleri J Med Sci 2008;28:154-9.

22. Platell C, Thompson P, Makin G. Sexual health in women following pelvic surgery for rectal cancer. Br J Surg 2004;91:465-8. [CrossRef]

23. Uçar T, Uzun Ö. Meme kanserli kadınlarda mastektominin beden algısı, benlik saygısı ve eş uyumu üzerine etkisinin incelenmesi. Meme Sağlığı Derg 2008;4:162-8. Erişim: http://www. thejournalofbreasthealth.com/sayilar/13/buyuk/1331.pdf

24. Kreis $H$, Loehberg $C$, Lux M, Ackermann S, Lang W, Beckmann $M$, Fasching PA. Patients' attitudes to totally implantable venous access port systems for gynecological or breast malignancies. Eur J Surg Oncol (EJSO) 2007;33:39-43. [CrossRef]

25. DeFrank JT, Mehta CCB, Stein KD, Baker F, editors. Body image dissatisfaction in cancer survivors. Oncol Nurs Forum 2007;34:625E41. [CrossRef]

26. Moreira $\mathrm{H}$, Canavarro M. A longitudinal study about the body image and psychosocial adjustment of breast cancer patients during the course of the disease. Eur J Oncol Nurs 2010;14:263-70. [CrossRef]

27. Tantleff-Dunn S, Gokee J. Interpersonal influences on body image development. In: Cash TF, Pruzinsky, editors T. Body image: A Handbook of Theory, Research, and Clinical Practice. New York: Guilford Press; 2002. pp.108-16.

28. Dedeli Ö, Fadıloğlu Ç, Uslu R. Kanserli bireylerin fonksiyonel durumları ve algıladıkları sosyal desteğin incelenmesi. Türk Onkoloji Derg 2008;23:132-9.

29. Özkan S. Kanserli hastada psikiyatrik ve psikososyal destek. In: Mandel NM, Onat H, editors. Kanser Hastasına Yaklaşım Tanı, Tedavi, Takipte sorunlar. Yenilenmiş 2. Baskı. İstanbul: Nobel Tıp Kitabevi; 2012. pp.533-40. 
30. Hocaoğlu Ç, Kandemir G, Civil F. Meme kanserinin aile ilişkilerine etkileri. Meme Sağlığı Derg 2007;3:163-6.

31. Tiryaki A, Özçürümez G, Sağlam D, Yavuz M. Meme kanseri olan kadınların eşlerinin hastalığa tepkileri. Anadolu Psikiyatri Derg 2010;11:95-101.

32. Romero C, Lindsay J, Dalton W, Nelson D, Friedman L. Husbands' perceptions of wives' adjustment to breast cancer: the impact on wives' mood. Psycho-Oncology 2008;17:237-43. [CrossRef]

33. Kılıç E, Taycan O, Belli AK, Özmen M. Kalıcı ostomi ameliyatının beden algısı, benlik saygısı, eş uyumu ve cinsel işlevler üzerine etkisi. Türk Psikiyatri Derg 2007;18:302-10. Erişim: http://www.turkpsikiyatri. com/C18S4/02kaliciOstomi.pdf

34. Cochrane BB, Lewis FM. Partner's adjustment to breast cancer: a critical analysis of intervention studies. Health Psychol 2005;24:32732. [CrossRef]

35. Wagner C, Bigatti S, Storniolo A. Quality of life of husbands of women with breast cancer. Psycho-Oncology 2006;15:109-20. [CrossRef]

36. Özer $A B$, Bayar MK. İmplante Edilebilir Venöz Port Kateter Uygulamalarımızın İncelenmesi. Fırat Tıp Derg 2011;16:6-10. Erişim: https://dergipark.org.tr/download/article-file/72212
37. Arch P. Port navigation: let the journey begin. Clin J Oncol Nurs 2007;11:485-8. [CrossRef]

38. Yeşil S, Tanyıldız H, Ardıçlı B, Tekgündüz S, Çandır M, Toprak Ş, et al. Santral Venöz Kateter Komplikasyonları. Gazi Med J 2014;25:135.

39. Gorski L. Standard 45: Implanted Ports and Pumps. J Infus Nurs 2008;31:20-1. [CrossRef]

40. Madabhavi I, Patel A, Sarkar M, Anand A, Panchal H, Parikh S. A Study of Use of "PORT" Catheter in Patients with Cancer: A Single-Center Experience. Clin Med Insights Oncol 2017;11. [CrossRef]

41. Viale PH. Complications associated with implantable vascular access devices in the patient with cancer. J Infus Nurs 2003;26:97-102. [CrossRef]

42. CHRISP. Totally implantable central venous access ports. Erişim: https://www.health.qld.gov.au/_data/assets/pdf_ file/0030/444486/icare-port-guideline.pdf

43. Chen $Y$, Yan $C$. Hematology-oncology port-A. improving nursing care quality. Hu Li Za Zhi 2011;58:64-72.

44. Kelsaka E, Güldoğuş F. Vasküler port uygulamalarımızın retrospektif değerlendirilmesi. Int J Hematol Oncol 2005;4:195. 